\title{
Shoot Pruning and Impact on Functional Equilibrium Between Shoots and Roots in Simultaneous Agroforestry Systems
}

\author{
Patrick E. K. Chesney \\ United Nations Development Programme* \\ Guyana
}

\section{Introduction}

Shoot pruning of the woody components in simultaneous agroforestry systems with annuals and perennials enhances the services they provide to the ecosystem functions and to human livelihoods. These services include organic inputs, such as biomass and plant nutrients. Shoot pruning of the woody components is now an essential management practice in simultaneous agroforestry systems to avoid competition for growth factors, such as light and nutrients.

The purpose of this chapter is to review the biophysical science of shoot pruning of the woody components in simultaneous agroforestry systems with annual crops. The evidence from field experiments carried out mainly in the humid tropics is used to examine the impact of this management practice on the functional equilibrium between the shoots and roots of the woody component and to elucidate how the tree recovers from shoot pruning.

Research has shown that the outcome of the ecological interactions between woody and non-woody components in a simultaneous agroforestry system depends on species selection, shoot pruning management and spatial and temporal association of the components. This chapter focuses on shoot pruning management.

This review chapter is important because shoot pruning management of service trees woody components - for the benefit of associated annual crops, and at the same time, for the maintenance of soil fertility and reduced environmental impact, remains an important determinant of the adoption of agroforestry systems.

\section{Adoption of simultaneous agroforestry systems}

Almost a quarter of a century ago, Raintree (1987) suggested that the adoptability of agroforestry technology depended on how well the technology is fitted to the social and environmental characteristics of the land use system. Further, this technology should possess the essential elements of productivity and sustainability. About one decade later,

\footnotetext{
* The views expressed in this publication are those of the author and do not necessarily represent those of the United Nations or UNDP.
} 
Kass et al. (1997) analysed the evidence from the field and identified seven biophysical elements which could be manipulated to make alley cropping, a very popular simultaneous agroforestry system with annual crops, more productive, sustainable and acceptable to small producers. Around the same time, Current et al., (1995), in assessing farmer adoption of agroforestry in Central America and the Caribbean, reported mixed results for the rate of adoption of alley cropping technology, suggesting that the technology was not yet well fitted to the social and environmental characteristics of the land use systems of the farmers.

Current and colleagues (1995) went on to report that many farmers who adopted agroforestry systems, practiced shoot pruning of the woody components to rejuvenate them, increase productivity and reduce their environmental impact, indicating that there was understanding of the importance of the biophysical elements of productivity and sustainability. A better understanding of the biophysical science of shoot pruning management may lead to greater adoption of agroforestry systems in the tropics where poverty rates are high and land management for food and agriculture remains a major concern to governments and development partners.

\section{What is known about the biophysical science of shoot pruning?}

In his review of the merits of alley cropping, Sanchez (1995) argued that the failure of this system has been the inability to demonstrate that competition between the trees and associated crops for growth factors can be managed.

Since 1995, a number of field studies have been carried out to elucidate the mostly negative biophysical interactions aboveground between agroforestry trees and associated crops, and the required tree management by shoot pruning to avoid the negative interactions. The intensity of shoot pruning to preserve the service attributes of agroforestry trees, relative to the associated crops, has also been reviewed.

The operating premise of shoot pruning management is that managing perennial tree species by frequent pruning is possible because affected plants tend to restore the functional balance between above- and below-ground plant organs through reducing root respiration, slowing or ceasing root growth or reallocating carbon from storage organs in roots and stems to shoot meristems to support tree regrowth (Chesney \& Vasquez, 2007; Eissenstat \& Yanai, 1997). The consequence of acropetal movement of carbon from roots and stems to shoot meristems to provide energy for new shoot growth and restoration of photosynthetic capacity is the death of roots and nodules and contribution of carbon and nitrogen to soil pools (Chesney \& Vasquez, 2007; Nygren \& Campos, 1995; Nygren \& Ramirez, 1993). This response mechanism by pruned trees is essential to recovery and sustainability of the treecrop system.

\section{What is not known about the biophysical science of shoot pruning?}

What has not been reviewed in a cogent way is the evidence from the field on the effects of aboveground tree management (primarily shoot pruning) on tree roots and nodules and the regrowth of pruned trees. A review of the correlative processes between shoots and roots as a result of shoot pruning will increase understanding of shoot pruning as an important management practice in agroforestry systems and enhance the contribution of trees to agroecosystems. 


\section{Shoot pruning}

\subsection{What is pruning?}

In the horticultural sense, pruning is the mechanical removal of vegetative and/or flowering and fruiting growth from a plant to regulate its size (Soule, 1985). This could take the form of thinning, the complete removal of individual branches or, heading, the trimming off of ends of branches. In the agroforestry literature, several manifestations of tree pruning are used and are reported as pollarding, coppicing or lopping, sometimes used interchangeably in the same article. For example, Islam et al., (2008) reported that Sesbania grandiflora L. can be pruned, lopped or pollarded for shoot development, forage production and green manuring purposes. That might be so, but it is important to understand each type of pruning and to associate them with their proper use.

The following definitions should provide some clarity as to the distinct practices these pruning terms refer to:

- Pollarding is the repeated pruning of branches at or near the same point, which results in a distinctive thick bushy appearance of the trees (Soule, 1985). This practice involves cutting off the crown of a tree. Typically, depending on pruning height and the needs of associated crops, pollarding allows a time window of 3-4 months where there is near zero completion for light. However, fine roots and nodules start to regrow at 2-3 months after pruning and competition for nutrients may occur.

- Coppicing is the periodic heading back of a small wood or thicket grown for this purpose in like manner from forest trees or shrubs (Soule, 1985). Essentially, this practice involves cutting the tree down to the stump and allowing it to regrow to maximise biomass production. This type of pruning provides a longer time window (46 months depending on species) in which there is near zero competition for light between coppiced tree and crop.

- Lopping is the cutting off e.g. of leafy branches or twigs from a tree (Akunda \& Huxley, 1990). The time window for renewal of interspecific competition for light is similar to trees managed by pollarding but may be less depending on branch autonomy for carbon uptake.

Comparatively speaking, coppicing is the most extreme of the tree cutting practices, usually involving cutting to a height of $10-30 \mathrm{~cm}$ above ground. Lopping, cutting off branches, commonly leaves stubs of about $30-100 \mathrm{~cm}$ long on $150-200 \mathrm{~cm}$ main stems, whilst pollarding is usually done at a height of $75-150 \mathrm{~cm}$ depending on the service function of the agroforestry tree.

In alley cropping, the pollard height of $75 \mathrm{~cm}$ is commonly used (Kass et al., 1997). When trees are used as live stakes for vegetables such as tomato, a pollard height of $150 \mathrm{~cm}$ is preferred (Chesney et al., 2000). In shaded coffee (Coffea arabica L.) systems, shade trees made up predominantly of Erythrina poeppigiana (Walp.) O.F. Cook, are both lopped and pollarded usually at a height of 1.5 - $2 \mathrm{~m}$ (Beer et al., 1998; Muschler et al., 1993).

Therefore, pollarding, coppicing and lopping are tree cutting practices used for different purposes and care should be exercised in the use of these terms in the agroforestry literature. Each practice exerts a different physiological stress on the service tree and this has implications for the correlative mechanism involved in tree recovery, time to restoration of 
service attributes to the tree and contribution to enhancing the agro-ecosystem. For instance it is importance to understand the organ source of carbon for regrowth. On one hand, if the tree stem is the organ source of carbon then tree pruning management by coppicing may contribute to decline and eventual death of the coppiced trees. On the other hand, lopping or partial pollarding (e.g. leaving one branch on the pruned stump) may lead to the growth of the retained branch at faster rate than other branches from shoots on the pruned stump (Chesney, 2008; Chesney \& Vasquez, 2007). This may be due to branch autonomy for carbon uptake independent of the needs of other developing shoots on the pruned stump and this may be species and season dependent (Sprugel, 2002; Sprugel et al., 1991).

\subsection{Why prune trees in agroforestry systems?}

Pruning agroforestry trees in simultaneous agroforestry systems, particularly in the humid tropics, enhances resource (mainly light) supply (Cannell, 1983) and controls the competitive ecological interaction between the trees and associated crops (Siriri et al., 2010; Bayala et al., 2008). Use of the available growth resources is by competitive interaction between species (Anderson \& Sinclair, 1993).

In alley cropping, tree-crop interaction for light exceeds or nullifies the positive contributions to soil fertility made by the service trees (Rao et al., 1998). Analysis of alley cropping data from Turrialba, Costa Rica (Kass, 1987) has shown negative $(-3 \%)$ or near neutral $(1 \%)$ estimates of overall interaction effect for commonly used E. poeppigiana and G. sepium hedgerow trees, respectively. In home gardens in the humid areas of Kerala, India, Chandrashekara (2007) recommended shoot pruning for 10 important tree species to avoid competition with associated understorey crops. Hedgerow pruning of mimosa (Albizia julibrissin Durazz) increased light interception and reduced water stress in maize crops (Kang et al., 2008). There is no doubt that shoot pruning of the service tree in a simultaneous agroforestry system with annual crops is a necessary management practice to avoid competition for light between the tree and crop and to enhance the performance of the crop, maintain the service attributes of the tree species and enhance contribution of residual fertility to the agro-ecosystem.

Pruning as a management practice, while widely practised, has received little analytical attention in agroforestry research and extension. About 15 years ago, van Noordwijk et al. (1996) acknowledged the need for more research on aboveground tree management (shoot pruning), particularly the effects on tree roots. Timmer and colleagues (1996) investigated the reasons why farmers prune trees and found that, rejuvenation and improvement of tree survival and productivity as well as a reduction of tree influence on its environment were the more important ones. More than one-half of the farmers interviewed applied intensive pruning i.e., cutting all main branches to or at the same distance from the trunk. Over the fifteen year period (1996-2011), a number of field experiments were carried out on the effect of aboveground tree management on tree roots and nodules as well as the correlative processes involved in tree regrowth. The results of these studies are examined below.

\subsubsection{Importance of branch retention on the pruned stump}

Before 1996, shoot pruning management tended to be the complete removal of tree canopy to a certain tree height (pollarding, coppicing) at least twice per year to coincide with the 
planting of annual crops. Marginal increases in crop performance and poor survival of the pruned trees, especially when pruning was more than twice a year, led researchers to realise that the preservation of service attributes of the tree when pruning frequency is more than twice per year required a change in pruning intensity from complete removal of all branches (complete pruning) to retaining at least a single leafy branch (partial pruning). Partial pruning when applied twice or more per year to the service tree was found to be better than increasing the frequency of complete pruning or leaving too many branches on the pruned tree stump at pruning.

Depending on the desired height of the retained stump, complete pruning may be achieved by coppicing, pollarding or lopping. On the other hand, partial pruning may be achieved through pollarding and lopping with the slight modification of retaining foliage on the intact branch. There is a history to partial pruning. Leaving one or two branches on the pruned tree stump is a traditional partial pruning practice in Costa Rican coffee farms (Somarriba et al., 1996), a practice that is sometimes referred to as 'lung branch' pruning in Asian tea (Camellia sinensis (L.) O. Kuntze) farms (Kandiah et al., 1984). Its utility to simultaneous agroforestry systems was scientifically investigated towards the end of the $20^{\text {th }}$ century.

In a series of experiments carried out at Turrialba, Costa Rica, Chesney \& Nygren (2002) and Chesney (2008) found that partial pruning (retention of a single branch representing about $5 \%$ of foliar biomass before pruning) conserved fine roots. The authors argued that this result may have been due to the maintenance of a sequence of axes leading from leaves to stem and root system for allocation of photosynthates. Partial pruning nearly doubled the total above-ground biomass and increased nitrogen accumulation in the above-ground biomass by $60 \mathrm{~kg} \mathrm{ha}^{-1} \mathrm{yr}^{-1}$ compared to complete pruning. In accordance with the principle of branch autonomy for carbon uptake (Sprugel et al. 1991), 75\% of new shoot growth occurred on the retained branch of partially pruned E. poeppigiana (Chesney, 2008). Sprugel (2002) posits that the critical characteristics of a branch's carbohydrate economy (e.g. photosynthesis, respiration, growth) are largely independent of the tree to which the branch is attached as long as light is the primary factor limiting photosynthesis and growth.

\subsubsection{Key species evaluated in agroforestry systems managed by shoot pruning}

The selection and use of suitable trees and shoot pruning regime remain important to successful annual crop production in simultaneous agroforestry systems in the humid tropics.

In terms of the woody component, the fast growing nitrogen-fixing leguminous trees that have shown tolerance to shoot pruning and that are used extensively in simultaneous agroforestry systems with annual crops include: G. sepium, Grevillea spp, Casuarina spp, Leucaena leucocephala (Lam.) de Wit, Erythrina spp, Eucalyptus spp and Sesbania spp.

Most of the studies done on simultaneous agroforestry systems with annual crops have disproportionately focused on maize (Zea mays L.) and beans (Phaseolus vulgaris L.), although some examples of studies on vegetables in simultaneous agroforestry systems have been reported. For example, work with vegetable crops associated with $\mathrm{N}$-fixing leguminous trees has been reported in various growing environments in the tropical zones of Africa (Nigeria, Ivory Coast), Asia (Philippines, India and Papua New Guinea) and the Americas (Costa Rica, Peru). The production of such crops like pepper (Piper nigrum L.) in 
India and yam (Dioscorea alata L.) in Nigeria and Costa Rica, are mainly in bush fallows although some form of alley cropping is practised, e.g. with tomato (Chesney et al. 2000). Sweet potato (Ipomoea batatas (L.) Poir) has been evaluated in an agroforestry system in Papua New Guinea (Brook, 1992).

In these systems, the shoot pruning height and frequency of pruning of the woody component depend on the needs of the associated crop and the tolerance of the woody component to frequent shoot pruning.

\subsubsection{Implications of shoot pruning}

In classical horticulture, the manner in which pruning cuts are made may extend or shorten the longevity of a tree while the invigorating effect of pruning depends on the time of year it is done and how much is pruned. For example, when a thinning cut is made to reduce density, care should be taken not to leave short stubs as these either dieback to the base or give rise to shoots from dormant buds located at the base of the stubs. These vigorous stubs divert energy from the tree.

Architecturally, branches are structurally attached to the trunk by a series of trunk collars that envelope the branch collars every growing season. When the trunk collar is injured or removed by branch pruning, the trunk xylem above and below the cut is rapidly and extensively infected and decay develops (Shigo, 1990). This is common in pruning management of agroforestry trees and is unavoidable as the benefits from more careful pruning may not offset the incident costs of pruning.

In agroforestry, it is the propensity of pruned stumps to regrow shoots from dormant buds that is exploited to ensure tree survival through shoot regrowth and restoration of physiological function to the tree. Dieback associated with shoot pruning cannot be avoided in managed agroforestry systems because of the objective and cost of shoot pruning, the latter being the main factor in situations where there is a shortage of labour.

In one of the few reported estimation of the cost of shoot pruning, van Noordwijk et al. (1997) calculated that pruning and maintenance of hedgerows (row $4 \mathrm{~m}$; pruning height 0.5$1 \mathrm{~m}$; regular pruning) require 80-100 person-days per year which may represent a large fraction of total amount of annual household labour available for farming (ICRAF, 1996). Brook (1992) reported that 108 man-days were required to manage the hedges of an experimental area of 0.24 ha in a single cropping season. This labour requirement could conflict with the farmer's peak demand for labour (Sanchez, 1995) and the opportunity cost inherent in delayed or less frequent pruning and increased competition may be too high. The cost: benefit analysis of shoot pruning has not been examined.

The deleterious effect of dieback is avoided when fast growing, nitrogen fixing trees are used in managed agroforestry systems and they are pollarded or lopped to retain at least one branch. The fast growth rate of the trees, and especially shoots on the retained branch, allow for rapid restoration of photosynthetic capacity to the tree in the regrowing vegetation on tree stumps. Dieback can be selectively removed in subsequent pruning.

There is an effect of season on shoot pruning. Trees pruned during the dry season resprout more vigorously compared to the response during the rainy season. Chesney \& Vasquez 
(2007) reported that pruned E. poeppigiana and G. sepium trees mobilised similar amounts of starch in roots and stems in the rainy season but more starch in stems in the dry season because sink demand was greater in the dry season when greater and faster resprouting occurred compared to the wet season. In that experiment, resprouting occurred two weeks earlier during the dry season compared to the wet season.

\subsubsection{How much aboveground biomass to prune?}

In horticulture, whatever the pruning regime, the rule of thumb is that pruning trees for delivering service functions to crop production should be done in a way to retain the correlative processes of apical dominance or apical control as well as the allocation mechanism to maintain feedback among the sources and sinks (Wilson, 1990), particularly with respect to biomass and nitrogen availability and use. These correlative processes are examined in section 3.2.

In agroforestry systems, shoot pruning removes apical dominance and attention is more focussed on the allocation mechanism between sources and sinks for carbon and nitrogen. How much to prune depends on species, canopy size, light needs of the crop and rate of recovery of the tree species. Shoot pruning amount is a function of height of pruning, shoot biomass at time of pruning and frequency of pruning in a cropping year.

Of three legume trees tested for rotational alley cropping, G. sepium appeared to be a suitable candidate species owing to its superior tolerance to long term pruning compared to E. orientalis and Calliandra calothyrsus Benth., which died back after 3 and 6 years, respectively (van Noordwijk et al., 1995). The physiological reason appears to be the rapid replenishment of starch in roots of G. sepium. In a study of the dynamics of non-structural carbohydrates reserves in pruned E. poeppigiana and G. sepium in Costa Rica, Chesney and Vasquez (2007) found that replenishment of starch in roots of G. sepium reached $70 \%$ of its initial concentration by 12 weeks after pruning. Root stores of starch in this species play an important role in its post-prune recovery and tolerance to pruning.

Increasing lopping height (1-1.5 $\mathrm{m}$ ) and reducing pruning frequency (2-3 times per year) not only maintain high biomass production over the long-term albeit, with a decreasing tendency over time (Keerthisena, 1995) but do lead to increased survivability of the trees. For example, Duguma et al. (1988) recommended that G. sepium should be pruned fewer than four times per year since this frequency of pruning could reduce tree stand by as much as $25 \%$. In a field experiment with Leucaena in Bangladesh, Tipu et al., (2006) found that pruning at $1.5 \mathrm{~m}$ height yielded the highest biomass compared to lower pruning heights.

Tree survivability to frequent pruning may be related to tree age. Duguma et al. (1988) opined that further studies are needed to examine the relationship between age of seedlings and pruning intensity on survival and biomass production. Although the elucidation of this relationship remains unrealised, some insights in research results have been provided. Chadhokar (1982) reported that frequent cuttings of young trees had a negative yielding effect on Gliridicia in later years. Chesney (2008), who reported that completely or partially pruned two year old E. poeppigiana tree yielded less aboveground biomass (4.4 or $7 \mathrm{Mg} \mathrm{ha}^{-1}$ $\left.\mathrm{yr}^{-1}\right)$ than eight-year-old trees $\left(5.5\right.$ or $\left.9 \mathrm{Mg} \mathrm{ha}^{-1} \mathrm{yr}^{-1}\right)$, similarly pruned although there is a 
higher investment in root growth in younger trees. Figures represent wet or dry season. Shoot pruning was carried out four times per year, during the two cropping seasons.

Partial shoot pruning is better than complete shoot pruning insofar as preserving tree survival, continuing ecosystem function and contributing biomass and nutrients in pruned shoots, nodules and fine roots to the agro-ecosystem (Chesney, 2008).

\section{Shoot pruning and correlative processes in trees}

\subsection{Functional equilibrium hypothesis}

The functional equilibrium hypothesis proposed by Brouwer $(1962,1983)$ contends that plants display a tendency to maintain a constant balance between growth rates of shoots and roots. The balance is regulated by the demand for plant resources such as non-structural carbohydrates and nitrogen. When nitrogen limits growth, root growth is relatively favoured and when the limiting factor is non-structural carbohydrate, which can occur after shoot pruning, aboveground growth is relatively favoured. Using these two growth factors to illustrate the point, the typical plant response in the restoration, or the establishment, of a new functional equilibrium between shots and roots, is to mobilise non-structural carbohydrate reserves in the stem or roots to support resprouting and early shoot growth. Research carried out by a number of researchers support this contention (Chesney \& Vasquez, 2007; von Fircks \& Snnerby-Forsse, 1998; Erdmann et al., 1993).

Kang (1993) posited that competition between trees and crops may be sufficient to outweigh the positive benefit of mulching especially on highly acidic and low moisture status soils. The selection of $\mathrm{N}$-fixing and fast growing trees may not be the solution rather there is an urgent need to look for complementarity in rooting of trees and crops. From the limited root studies undertaken with leguminous trees in vegetable production, G. sepium presented little competition when associated with a yam crop (Budelman, 1990). Soil tillage in planting strips of crops could reduce competition from superficially rooted trees or covercrop in addition to facilitating contribution of organic matter and nutrients from cut roots. There is an insufficient body of published literature on this topic to evaluate its usefulness as a management practice or to compare with shoot pruning.

\subsection{Shoot pruning and correlative processes}

The previous sections have established that shoot pruning management of the woody component in simultaneous agroforestry systems such as alley cropping is a standard practice to avoid competition for growth resources (e.g. light, water, nutrients) between the woody and non-woody components. Field research support the contention that shoot pruning enhances resource (such as light) supply and use of the resource is by competitive interaction between species (Anderson \& Sinclair, 1993). In some simultaneous agroforestry systems such as alley cropping, without tree pruning management, the tree-crop competition for light exceeds or nullifies the positive contributions to soil fertility made by the service trees (Ong et al., 1996).

Reviews of alley cropping have shown that there is soil improvement through mulch effect (Oelbermann \& Voroney, 2010; van Noordwijk et al., 1997) but competition for light, water 
(especially in the dry tropics) and nutrients could outweigh its advantage (Sanchez, 1995; van Noordwijk et al., 1997). This finding led to a system-based approach to avoid the negative tree-crop interaction in simultaneous agroforestry systems was pursued. Rotational alley cropping where trees are still in hedgerows but cropping is not continuous, in other words, a phasic alternation of tree and crop, was introduced. During the crop phase, trees are severely cut back by shoot pruning near to ground level (coppicing) to reduce interspecific competition as well as labour for pruning, yet the tree stumps are supposed to survive and allow a quick regrowth of trees after 1-3 years of cropping. Candidate trees for this system must survive the setback of pruning and develop a proper tree canopy when left to grow (van Noordwijk et al., 1997). This approach may reduce competition for light between tree and crop but the required frequent soot pruning of the woody component may affect its survivability, and therefore the choice of shoot pruning method assumes high importance.

For that kind of intensive shoot pruning management (coppicing), it is important to select trees species that store adequate amounts of carbohydrates in the roots to provide the energy for resprouting and rapid regrowth of above ground parts. Shoot regrowth from other less intensive shoot pruning (pollarding or lopping) could be energetically supported from carbohydrate stores in stems and roots of the pruned tree stump.

Shoot pruning alters the growth and development of trees at different organ levels. This practice changes the leaf area and photosynthetic capacity of a tree. Also, it is thought to affect the metabolic equilibrium between the above- and below-ground organs by reducing the amount of growing shoots that function as sources and sinks for nutrients and hormones. Shoot pruning could cause death of fine roots and nodules under some conditions because of inadequate carbohydrate supply and so temporarily interrupt the nitrogen fixing ability of the tree.

\subsubsection{Effect of shoot pruning on nodules}

Shoot pruning affects root nodulation and temporarily interrupts the nitrogen fixing ability of leguminous tree. Fownes \& Anderson (1991) reported nodule loss after cutting S. sesban and L. leucocephala in a pot study, which was relatively greater that root loss, but recovery to uncut equilibrium occurred within two weeks of shoot pruning. They suggested that a

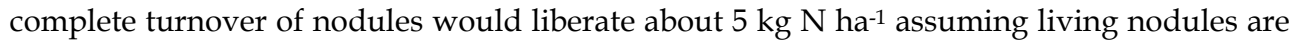
approximately $10 \% \mathrm{~N}$, there is no reabsorption of nitrogen out of senescing nodules and that nodule decomposition is rapid. Chesney \& Nygren (2002) reported that nodules of $E$. poeppigiana may be more sensitive than fine roots to aboveground disturbance, which may be more pronounced in older trees (8-year-old) compared to younger trees (2-year-old). During the time when nodulation is affected, tree requirements for nitrogen would be met from uptake of mineral nitrogen. New nodules and fine roots of E. poeppigiana are initiated from 10-14 weeks after pruning (Chesney \& Nygren 2002; Vaast \& Snoeck, 1999).

G. sepium nodulates mostly on lateral roots. Parrota \& Singh (1992) found first order laterals of 0.9-2.5 m long in the upper $20 \mathrm{~cm}$ of soil in Puerto Rico, where most plant available nutrients are found. This would suggest that in addition to shoot pruning, soil tillage in the crop planting rows could manage potential inter-specific competition for growth factors. 
The strain of Rhizobium has an effect on the nitrogen fixing potential of G. sepium. Awonaike et al. (1992) observed that di-nitrogen fixation and general performance could be either low or high depending on inoculum strain. The nitrogen derived from transfer (Ndft) when G. sepium was in association with Bradyrhizobium and Rhizobium was $47 \%=20 \mathrm{mg}$ N per plant and $61 \%=28 \mathrm{mg} \mathrm{N}$ per plant, respectively.

\subsubsection{Effect of shoot pruning on fine roots}

Above-ground pruning is known to cause death of fine roots under some conditions because of inadequate carbohydrate supply (Fownes \& Anderson 1991; Erdmann et al., 1993). Other factors contributing to root death are natural senescence and water stress. Govindarajan et al. (1996) reported that the first pruning of Leucaena in the semi-arid highlands of Kenya did not induce root death because root system was least active towards the end of the dry season. Root growth started with the commencement of rains. As rainfall declined and water stress sets in, root death occurred. Shoot pruning at this time accelerated root death. The researchers found that nutrient contribution through fine root turnover of hedgerows for crop growth to be small compared to aboveground biomass.

Chesney \& Nygren (2002) reported that nodule and fine root turnover as a result of shoot pruning was compensated for by new production at 10-14 weeks after pruning thus corroborating earlier observations that E. poeppigiana requires 10-16 weeks to renew $\mathrm{N}_{2}$ fixation (Vaast and Snoeck, 1999). Half yearly (Nygren and Ramirez, 1995) or four (Chesney and Nygren, 2002) shoot prunings per year resulted in complete turnover of nodules and over 50\% decrease in fine root mass (Nygren and Campos, 1995; Muñoz and Beer, 2001). The authors concluded that the retention of a branch on the pruned E. poeppigiana allow better fine root and nodule survival and enhances tree biomass production.

Further evidence of how aboveground biomass retention influences root behaviour was presented by other researchers. Fownes \& Anderson (1991) reported that fine root biomass was correlated with leaf biomass in uncut tress but cutting disrupted this equilibrium. Akinnifessi et al. (1995) working with Leaucaena hedgerows on an alfisol found fewest roots in regularly pruned hedgerows with prunings removed. Fewer structural roots were present in topsoil when continuous pruning and no alley cropping and prunings removed were applied. Regular removal of pruning biomass reduced abundance of fine roots by $61.4 \%$ and increased the number of roots by $24 \%$. The abundance of structural roots ( $>20 \mathrm{~mm}$ ) was not significantly affected by hedgerow pruning and cultivation and a shift from fine root to coarse root was observed in unpruned trees. Regular pruning and biomass export from the plot significantly depressed fine root growth by $88 \%$ compared to unpruned hedgerow. Hedgerow pruning and cultivation (root pruning especially with hoe-weeding) can be used to reduce presence of structural root growth in the plough layer.

Another potential indicator of tree productivity is stem basal diameter as suggested by Parotta \& Singh (1992). The researchers worked with G. sepium and found stem basal diameter to be a good predictor of both shoot and root biomass, which could in turn could be correlated with tree regrowth potential and contribution of biomass and nutrients to soil. Further work is needed to test the goodness of this indicator in an agroforestry system where trees are managed by periodic shoot pruning. 


\subsubsection{Resprouting of pruned trees}

Shoot pruning affects the physiological processes of photosynthesis and non-structural carbohydrate synthesis. Non-structural carbohydrate reserves, mainly starch provide the energy to drive regrowth of pruned trees. Starch provides energy for respiration of active buds and synthesis of chlorophyll, proteins and structural compounds during early stages of leaf growth, processes that influence the rate of resprouting and biomass output of pruned trees. Other factors that affect the regrowth of pruned trees include the severity of disruption to the photosynthetic capacity and the resprouting rate.

Chesney and Vasquez (2007) found that the critical tree regrowth stage for starch mobilisation was that of vigorous sprout development at six or four weeks (depending on wet or dry season) after pruning, particularly in completely pruned trees. The authors reported that there was an important species difference with respect to starch replenishment in trees regrowing from pruning. For G. sepium, starch accumulation in roots recommenced at 12 weeks after pruning compared to E. poeppigiana roots where starch accumulation recommenced later than 12 weeks. At that time, new nodules and fine roots are produced in these species.

In a study with E. fusca Lour. and G. sepium in the humid Atlantic lowlands of Costa Rica, Muschler et al. (1993) found that of these trees pollarded twice per year, G. sepium was the first to resprout. Its crown base after four months shifted upward at maximum diameter in a form which allows for good light transmission to the associated crop while E. fusca continued to expand and achieved crown closure at six months of regrowth thus not permitting penetration of photosynthetically active radiation into the stand. Since the main consideration is on labour saving in pruning but with reduced competition, the authors concluded that $G$. sepium appears best for this role.

The implications for associated crop management are several. Since shoot pruning removes competition for light between the tree and associated crop, it also provides a time window of almost one month when no competition in the soil can be expected between tree and crop roots for plant available nutrients. Transplanting of crop seedlings can then be made at shoot pruning to aid the early growth of seedlings. Depending on the needs of the crop, another shoot pruning of the agroforestry trees may be needed during the life of the crop, preferably before the onset of the reproductive phase of crop development.

\section{Tree pruning and contribution to ecosystems}

\subsection{Biomass and carbon pools}

The management of both tree and crop for the benefit of the crop and at the same time for maintenance of soil fertility and reduced environmental contamination is the main challenge to farmers and researchers alike. The nature of the interaction depends mainly on species selection, pruning management of the trees and time of association.

Erythrina spp. produce more above-ground biomass than G. sepium when similarly pruned (Table 1). These data are site specific but serve as a useful guide to biomass yield from trees managed by periodic shoot pruning in agroforestry systems. Increasing tree density and pruning frequency did not increase the biomass output of G. sepium. Chesney (2008) 
reported that increasing pruning frequency increased biomass yield and available nitrogen, a finding that depends on species and ecosystem type.

\begin{tabular}{|l|c|c|c|c|l|}
\hline \multicolumn{1}{|c|}{ Tree species } & $\begin{array}{c}\text { Tree density } \\
\text { (plants/ha) }\end{array}$ & $\begin{array}{c}\text { Pruning } \\
\text { frequency }\end{array}$ & $\begin{array}{c}\text { Tree biomass } \\
\mathbf{( M g} \\
\text { DM/ha/yr) }\end{array}$ & $\begin{array}{c}\text { Available } \\
\mathbf{N}(\mathbf{k g} / \mathbf{h a})\end{array}$ & \multicolumn{1}{|c|}{ Source } \\
\hline E. berteroana Urb. & 1,600 & Twice/year & 3.8 & 146 & $\begin{array}{l}\text { Muschler et al., } \\
1993\end{array}$ \\
\hline E. poeppigiana & 1,666 & Four/year & $4.9-8$ & $141-221$ & Chesney, 2008 \\
\hline E. fusca & & & 3.4 & 124 & \\
\hline G. sepium & & & 2.3 & 90 & \\
\hline & & & $2-7$ & & Otu \& Agboola, \\
\hline G. sepium & 2,500 & Thrice/year & 2.1 & & 109 \\
\hline & & & & Brook, 1992 \\
\hline
\end{tabular}

Table 1. Biomass production of $\mathrm{N}$-fixing trees used in simultaneous agroforestry systems

Effect of pruning on performance of tree species varies. Siriri et al., (2010) reported that pruning increased survival in Calliandra spp., reduced survival in Sesbania spp. while Alnus spp. was unaffected by pruning.

In some cases, continual pruning can reduce dry matter yield over time. Keerthisena (1995) reported that annual shoot dry matter yield decreased from a maximum of $9 \mathrm{t} \mathrm{ha}^{-1}$ in year 2 , to $4.3 \mathrm{t} \mathrm{ha}^{-1}$ by year 5 , which would still be adequate to maintain soil fertility at a desirable level in the sub-humid tropics (Young, 1981). Increasing lopping height increased shoot dry matter yield meaning more food reserves available for vigorous regrowth. Difference in dry matter yield between short and tall trees will increase in time showing a decreasing trend in annual shoot dry matter yields at high levels. According to Karim \& Savill (1991), 2 m wide alleys produced 2.8 times more biomass than $4 \mathrm{~m}$ wide alleys at first harvest one year after tree establishment. However, short term yield of tree biomass in hedgerows was not found to be a useful predictor of long-term yield (Keerthisena, 1995).

Kang (1993) proposed that there is functional similarity of trees in alley cropping and bush fallows which include the provision of nitrogen from atmospheric fixation, recycling of nutrients, suppression of weeds and increasing organic matter content. During the cropping phase, which alternates with a bush fallow, the stumps of the trees help to re-establish woody vegetation, which can partially restore soil fertility during the fallow period. In alley cropping, trees and crops grow together, not necessarily at the same rate but do present opportunity for interaction. In some species, woodiness appears from week 4 onwards, and as long as the interval of successive shoot pruning is greater than four weeks, biomass yield will be greater.

\subsection{Pruning and nitrogen dynamics}

Research has shown that partial shoot pruning is preferred to complete shoot pruning to preserve the service attributes of trees, including biomass production, nutrient availability and faster tree recovery. 
Before a managed tree can be of use to the agroforestry system to which it is a part, it must fulfil its own needs. In terms of fulfilling its nitrogen and phosphorous requirements, $G$. sepium seems a very efficient tree. Liyanage et al. (1994) reported that Gliricidia could obtain some $64 \%$ of its nitrogen from the atmosphere under field conditions. Duhoux \& Dommergues (1984) quantified N-fixation in G. sepium to be about $13 \mathrm{kgN} \mathrm{ha}^{-1} \mathrm{yr}^{-1}$. The requirement of this species for phosphorous seems to have been met by mycorrhizal association. Mulongoy (1983) reported an infection of 25 to $82 \%$ suggesting that Gliricidia can thrive well in soils low in available phosphorous.

It has been reported that some $40 \mathrm{~kg} \mathrm{~N}$ could be available to associated crops from the biomass of G. sepium (Kang \& Mulongoy, 1987). van Noordwijk and colleagues (1997) calculated that the nitrogen yield of prunings from trees pruned twice is usually not more that the equivalence of $60 \mathrm{~kg} \mathrm{~N}$ as urea per crop. Taking a conservative estimate of labour costs of pruning as 20 man-days ha- ${ }^{-1}$ cycle $^{-1}$, these authors made the interesting observation that the rewards for this labour are $1.5 \mathrm{~kg}$ urea day-1 or US\$0.38 day-1. They concluded that although trees can be successful in a supportive role from a biophysical point of view, farmer acceptance of such technology is more likely if the trees have a productive role as well.

Shoot pruning or shading can reduce the rate at which legume plants fix nitrogen. Ryle et al. (1985) found that defoliation reduced the rate of $\mathrm{N}$-fixation, photosynthesis and respiration by $>70,83-96$ and $30-40 \%$, respectively. The original rates of $\mathrm{N}$-fixation were attained after one week's growth. Siddique \& Bal (1990) reported that the rate of $\mathrm{N}_{2}$ fixation decreased at night and under shady conditions during the day. Thus, any shading and/or defoliation which diminish photosynthate supply can also limit the fixation of nitrogen.

Several authors have shown the high contribution of nitrogen in aboveground biomass of $E$. poeppigiana. Both Beer (1988) and Kass et al., 1993) have reported N-yield in excess of $250 \mathrm{~kg}$ $\mathrm{N}$ ha $\mathrm{yr}^{-1}$ of trees managed by twice-yearly complete pruning. Chesney (2008) reported the amount of $\mathrm{N}$ cycled in aboveground biomass was 123 or $187 \mathrm{~kg} \mathrm{ha}^{-1}$ (2 year old trees) and 160 or $256 \mathrm{~kg} \mathrm{ha}^{-1}$ (8 year old trees) when managed by complete or partial pruning, respectively.

Using the nutrient requirements of certain 'stakeable' vegetables that could be included in simultaneous agroforestry systems, it is clear how their major nutrient needs could be met from nutrient content of pruned biomass (Table 2). However, continuous cultivation of annual crops on many humid tropical soils leads to a decline in nitrogen availability and total soil nitrogen (Sanchez et al., 1983). Palm (1995) reported that legume mulches applied at the realistic rate of $4 \mathrm{tha}^{-1}$ yielded $8-12 \mathrm{~kg} \mathrm{P} \mathrm{ha}^{-1}$. Sanginga and colleagues (1994) reported that irrespective of pruning treatments in G. sepium more total $P$ was allocated to stems than to leaves and branches suggesting a possible role in tree regrowth and consequently, less availability for turnover.

\begin{tabular}{|l|c|c|c|c|c|}
\hline \multirow{2}{*}{ Crop } & \multirow{2}{*}{$\begin{array}{c}\text { Yield } \\
\mathbf{k g} / \mathbf{h a})\end{array}$} & \multicolumn{2}{c|}{ Nutrient requirement $\mathbf{( k g} / \mathbf{h a})$} & \multirow{2}{*}{ Source } \\
\cline { 3 - 5 } & $\mathbf{N}$ & $\mathbf{P}$ & $\mathbf{K}$ & \\
\hline Tomato & 14,500 & 98 & 11.88 & 118.69 & IICA 1989 \\
\hline Cucumber & 10,900 & 45 & 15.84 & 58.93 & IICA 1989 \\
\hline Black pepper & 350 & 75 & 49.5 & 46.5 & De Geus 1973 \\
\hline
\end{tabular}

Table 2. Nutrient needs (based on extractive potential) for selected vegetables. 


\subsection{Quality of biomass and nutrient release}

Myers and colleagues (1994) stated that the synchronisation of nutrient release from plant residues and uptake by plants is a central paradigm in applied soil biological research. This concept was earlier developed by Swift (1985) and elaborated by Haggar et al. (1993).

The rate of decomposition and the amount of nitrogen mineralised from plant residues determine the short-term benefits of tree pruning to crop nitrogen uptake. Efficiency of use of nitrogen in plant residue depends on the rate of decomposition affected by the ratio of nitrogen:polyphenol:lignin (Palm \& Sanchez, 1991), mineralisation as affected by the C:N ratio (Weeraratna, 1979), and protein binding (Handarayan et al., 1997). Gliricidia has a C:N ration of 10, low lignin content of $3.9 \%$ and could lose $50 \%$ of initial P after 20 days of decomposition (Mulongoy, 1983). Wilson et al., (1986) reported that rate and extent of dry matter loss from Gliricidia leaves is much faster under high rainfall conditions. Budelman (1986) reported that leaf mulch decompose rapidly with a half-life of 20 days.

Handarayan et al. (1997) suggested that the nitrogen mineralisation rate of prunings may be manipulated by mixing different quality materials such as high quality tree prunings of $G$. sepium and low-quality legume tree prunings such as Peltophorum dasyrachis (Miq.) Kurz. Pruning two weeks before transplanting vegetable seedlings and mulching with pruning may confer more efficient nutrient use on the agro-ecosystem.

\section{Correlative processes in a pruned tree}

\subsection{Pruning and the physiology of tree regrowth}

Pruning alters the growth and development of trees at different organ levels (Genard et al., 1998). This practice changes the leaf area and photosynthetic capacity of a tree. Also, it appears to affect the metabolic equilibrium between the root system and the aerial part of the tree by reducing the amount of growing shoots that function as sources and sinks for nutrients and hormones (Grochowska et al., 1984). Pruning height at or above $1.5 \mathrm{~m}$ seems to be best for tree survival and regrowth owing to a higher number of resprouting buds that may occur on a taller pruned stem (van Noordwijk \& Purnomosidhi, 1995).

Like fruit load in horticultural species, biomass may also affect starch dynamics. Root starch levels drop for trees when fruit is removed and this mobilised starch is used for vegetative flushing in mango (Davie \& Stassen, 1997). Lowering of root starch level in support of regrowth may lead to a decrease in total wood starch. Removal of canopy by shoot pruning reduced starch content as well. Erdmann and colleagues (1993) reported that G. sepium use stem starch to support initial coppice shoot regrowth after cutting and this carbohydrate was present in sufficient concentration to preclude use of root reserve carbohydrate.

Fownes \& Anderson (1991) indicated that apparent equilibrium between leaf biomass and roots and nodules and similarly of stem growth efficiency between cut and uncut treatments suggest that coppice shoots behave physiologically much the same as original shoots. 


\subsubsection{Role of starch}

According to Chesney \& Vasquez (2007), shoot pruning affects the processes of photosynthesis and synthesis of non-structural carbohydrates. This means that energy for tree regrowth comes from reserves of non-structural carbohydrates, mainly starch (Loescher et al, 1990) stored in the pruned tree. Starch provides energy for respiration of active buds and synthesis of chlorophyll, proteins and structural compounds during early stages of leaf growth. These are processes that influence the rate of resprouting and biomass accumulation in pruned trees. The organ donor of starch during tree regrowth may be species specific. In some species, stem starch is more depleted than root starch (Chesney \& Vasquez, 2007; Erdmann et al., 1993).

von Fircks \& Sennerby-Forsse (1998) in a pot study with Salix viminalis L., usually used for biomass production in short rotation coppice plantations (Sennerby-Forsse \& Christersson 1994), found that this species had a high capacity for resprouting. After pruning, regenerating stems rely on internal carbon and nutrient reserves (Dickman \& Pregitzer 1992) mainly comprising carbohydrates, lipids and proteins (Dickson, 1991). Carbohydrate reserves in roots and stumps are important in resprouting of coppiced trees but starch is more important as a sensitive indicator of sprouting ability than other carbohydrates.

In their study with E. poeppigiana and G. sepium, Chesney \& Vasquez (2007) found that starch reserves were higher in roots than in stems, a finding consistent with that reported by Loescher et al. (1990). Depletion in starch levels starts in stems than in roots owing to a higher correlation with developing stem sprouts. This is related to the sink strength being greater at the utilisation site in meeting the respiratory energy demand of regrowing shoots. Typically, starch reserves closest to sites of greatest sink activity, e.g. developing stem sprouts, are depleted first (Kozlowski, 1992). Therefore, shoot pruning creates a demand for starch to support stem bud development into sprouts. This effect is stronger during the dry season compared to the wet season (Chesney \& Vasquez, 2007). Rapid biomass accumulation and rapid replenishment of tree reserves (Chesney, 2008; Loescher et al., 1990) increase the tolerance of woody perennials to pruning which helps to explain the findings of Duguma et al., 1988, and are critical to the sustainability of low input agroforestry systems as observed by Beer et al. (1990).

\subsubsection{Role of nitrogen}

Greater nitrogen availability increases shoot growth. There is increased utilisation of photosynthates and lower carbohydrate availability for storage in high nitrogen containing plants. During pre-dormancy, roots of lower nitrogen plants contained significantly more starch than roots of higher nitrogen plants thus roots play an important role in starch storage under low nitrogen conditions. From dormancy to regrowth, starch continues to decrease particularly in root phloem and cortical cells. This decrease may be attributed to the conversion of starch to sugars and the translocation of sugars to expanding buds for use in regrowth. Tschaplinski \& Blake (1994) investigated the influence of decapitation of actively growing hybrid poplars and found that 10 days after, stem starch concentration declined to $50 \%$ that of intact plants as a result or resprouting. 
Greater fine root length increases the capacity of trees to absorb available nitrogen. Partially pruned trees maintain fine roots and nodules for nutrient uptake and transport, and nitrogen fixation, respectively (Chesney and Nygren 2002). The retention of the branch on the pruned stump conserves more fine roots compared to complete pruning. Chesney (2008) found that the respective mean root length was 489 or $821 \mathrm{~m}$ (2 year old trees) and 184 or $364 \mathrm{~m}$ (8 year old trees) for trees pruned completely or partially. Corresponding nitrogen accumulation in aboveground biomass was 123 or $187 \mathrm{~kg} \mathrm{ha}^{-1}$ and 160 or $256 \mathrm{~kg} \mathrm{ha}^{-1}$.

In addition, there appears to be a role for nitrogen in the growth of resprouting shoots (Chesney \& Vasquez, 2007; Kabeya \& Sakai, 2005). The level of nitrogen storage whether in roots or stems is important for the growth of resprouting shoots since shoot pruning causes death of fine roots and nodules. In species that show good potential for rapid regrowth after shoot pruning, there is higher concentration of nitrogen in roots than shoots.

\subsection{Evidence from other ecological interactions}

\subsubsection{Perennial legume covercrops}

Perennial legumes, which thrive under shade, could be good candidates for inclusion in agroforestry systems with an emphasis on soil conservation. The results from studies with peanut (Arachis hypogaea L.) could be validated for a perennial legume such as Arachis pintoi Krapov \& W.C. Gregory. Siddique \& Bal (1990) found that peanut, unlike other known grain legumes, can sustain N-fixation when prolonged periods of darkness or de-topping curtail supply of photosynthate to the nodule. This ability to withstand photosynthate stress is attributed to the presence of lipid bodies in infected nodule cells. Apparently, the $\mathrm{N}_{2}$ fixation is not limited to photosynthate but rather by utilisation of carbon within the nodule (Vance \& Heichel, 1991). Interestingly, the inclusion of legume cover in a crop rotation for 3-6 months could benefit soil fertility via its organic matter input (2-3 $\left.\mathrm{Mg} \mathrm{ha}^{-1}\right)$ aboveground and $\mathrm{N}$ input (60-90 $\mathrm{ka} \mathrm{ha}^{-1}$ ) (Hairiah et al., 1992). This can lead to yield advantage in subsequent crops (van Noordwijk et al., 1995).

The use of legume covercrop in a simultaneous agroforestry system may have similar benefits to the use of fast growing nitrogen fixing trees but may also require management like shoot pruning of trees to remove competition, not for light, but for nutrients with the crop. Together, shoot pruning of trees and covercrop may yield substantial benefits to the crop and agro-ecosystem.

\subsubsection{Nitrogen derived from transfer}

Exactly what will happen to the nitrogen dynamics if a leguminous covercrop is included in an agroforestry system with leguminous $\mathrm{N}$-fixing trees is not altogether clear. It has been found that grasses growing in association with Gliricidia or Leucaena could derive up to $21 \%$ of $\mathrm{N}$ as $\mathrm{N}$ derived from transfer ( $\mathrm{Ndft}$ ) (Jayasundara et al., 1997). The authors were however cautious to note that Ndft is apparent nitrogen transfer since additions of nitrogen rich plant residue from $\mathrm{N}_{2}$ fixing legumes in mixture could stimulate mineralisation of 
native N from soil organic matter (Birch \& Dougall 1967). Catchpoole \& Blair (1990) and Rao \& Giller (1993) found 7-32 Ndft for grass growing with Gliricidia and Leucaena under controlled environmental conditions.

The transfer of nitrogen from legumes to associated grass is believed to occur through senescence and decomposition of leaf litter, fine root and nodule turnover, root exudation and direct transfer through interconnected mycorrhizal hyphae (Giller et al., 1991). Relative importance of each mechanism depends on duration of cropping system, intimacy of component crops and nature of management. There is recognition that $\mathrm{N}_{2}$ fixing legumes must be in some form of stress for significant nitrogen transfer to occur. Perhaps, in the presence of a perennial leguminous covercrop, $\mathrm{N}$-fixing trees may subserve its $\mathrm{N}$-fixing role. Pruning both legume components before crop establishment may be beneficial to the system in two ways. Firstly, more biomass and nitrogen available for the crop, and secondly, Arachis may be able to continue $\mathrm{N}$-fixation without diminishing soil nitrogen, something that completely pruned trees are not able to carry out. On the other hand, partially pruned trees could maintain system nitrogen absorptive capacity.

Complete shoot pruning may lead to more available nitrogen present in soil solution through residue decomposition. The death of fine roots could reduce the ability of tree to absorb nitrogen leached beyond the crop-rooting zone especially in a humid environment. This occurrence is more important for the first pruning, when no crop is present or is mature enough, to absorb a lot of available nitrogen and thus may lead to high nitrogen losses. Moreover, before first pruning a high amount of surface litter (accumulation through leaf dropping during dry season) is already present (Vanlauwe \& Sanginga 1995). Partial pruning (i.e. thinning trees to one or more apical branches) increases percent nitrogen in crop since there is a reduction in crop/tree competition for light and part of the canopy to maintain ability of trees to absorb nitrogen.

Cutting of legume trees does not always result in negative effects of the trees. Miquilena et al. (1995) in applying a cutting regime of 6, 9 and 12 weeks and planting density of $2 \times 1 \mathrm{~m}$ or $2 \times 2 \mathrm{~m}$ found high total nitrogen in Gliricida and this was not affected by density or cutting frequency.

\section{Models and pruning management}

Mathematical modelling could provide useful stopgap information on pruning effects generation utilising existing information garnered through alley cropping other annuals. This approach seems even more attractive given the need to reflect social, economic and environmental relevance.

Carbon based ecophysiological models, which integrate photosynthesis and respiration functions, exist. Some of these models consider interactions between tree root systems and aerial parts to provide a sound conceptual frame for studying these models. They do not consider the structure of the tree to be pruned. According to Génard et al. (1988), some models integrate morphological development and physiological processes. Using a carbon balance model of growth and development to study the pruning response, these researchers found that the rhythmicity of growth was enhanced by pruning and might result from 
variations induced in the root:shoot ratio. Variation in pruning severity has a greater effect that variation in pruning date and that tree growth was mainly dependent on assimilate availability.

The model of Barteling (1998) could be modified to study conditions for dynamic distribution of dry matter using mechanistic and allometric relationships between tree components. This could allow for a quantification of competition for resources on growth and development of crops. Using another important function, McIntyre et al. (1996) argued that evapo-transpiration can be predicted for a variety of canopy systems when light interception measurements are used in conjunction with a simple model of plant water uptake. The delay of hedge pruning until after the annual crop is established could result in greater water utilisation by the hedges and consequently, reduced evaporation. The roots of adult fruiting trees are more susceptible to prolonged soil drying that rots of seedlings, irrespective of form similarity (Espeleta \& Eissenstat, 1998). For forest ecosystems, the most frequently suggested cause of root death is water deficit (Persson, 1979).

Chesney \& Nygren (2002) applied the compartment flow model to fine root and nodule biomass and necromass measured in sequentially taken core samples in an alley cropping system with E. poeppigiana in Costa Rica. They found that the model provided more reasonable estimate of nodule dynamics than for fine root data. Nodulation was not interrupted in partially pruned trees as it did in completely pruned trees.

Oelbermann \& Voroney (2010) reported on the usefulness of the Century Model to predict soil organic carbon stocks in a Costa Rican soil amended with organic residues from periodic pruning.

\section{System-wide benefits of shoot pruning}

Shoot pruning as a management practice, can determine the contribution of woody perennials to food and agricultural productivity as well as environmental issues such as carbon sequestration at the farm and landscape levels.

At the farm level, (ecological) sustainability of production is more limited by biophysical rather than socio-economic or institutional factors (Poudel et al., 1998; Kass et al., 1997). Management strategies of soil conservation, appropriate cropping sequence and plant protection, packaged in agroforestry practices may have even greater relevance at the watershed level (Lindarte \& Benitez, 1993). For example, use of biomass of G. sepium could be the most appropriate way to recuperate degraded soils in the watershed areas in Central America (Jiménez et al., 1998). Thus, shoot pruning as a management practice to avoid competition for light between the fast growing, $\mathrm{N}$-fixing tree and crop also contributes high quality tree biomass to the ecosystem for its restoration and maintenance of health. Partial shoot pruning can help keep nitrogen from being leached into waterways or volatilised into the atmosphere by maintaining a nitrogen absorptive capacity in the retained shoots, a phenomenon emphasised by the branch autonomy for carbon.

Biomass accumulation is critical to the sustainability of low-input agroforestry systems. Biomass accumulation and rapid replenishment of tree reserves increase the tolerance of 
woody perennials to shoot pruning. In agroforestry systems, managed trees can sequester between 39-102 t C ha-1 $\mathrm{yr}^{-1}$. Albrecht \& Kandji (2003) estimated the carbon sequestration potential of agroforestry systems to be between 12 and $228 \mathrm{Mg} \mathrm{ha}^{-1}$.

Given that worldwide some 630 million hectares of unproductive cropland and grassland are available for agroforestry land use, the potential for carbon sequestration using an average value of $50 \mathrm{t} \mathrm{C} \mathrm{ha-1}^{-1}$ is 45 billion $\mathrm{t} \mathrm{C}$. In some agroforestry systems, the woody

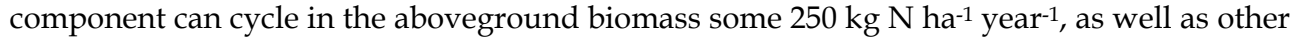
plant nutrients such as phosphorous and potassium.

\section{Conclusions}

Shoot pruning, as a management practice in simultaneous agroforestry systems with annual crops, has the high potential to assist farmers and agroforestry practitioners avoid negative ecological interaction between the service trees and associated food crops. Most of the service trees are fast growing, nitrogen fixing leguminous trees that have certain attributes that allow them to withstand periodic pruning, recover rapidly and contribute biomass and nutrients to the agroforestry system.

Physiologically, the storage of high amount of non-structural carbohydrates play an important role in tree recovery after pruning and the organ source of non-structural carbohydrates is an important determinant of how much to prune and when to prune.

Shoot pruning that retains some photosynthetic capacity on the pruned stump is preferable to complete removal of all shoots as it enables the trees to continue to function and contribute inputs to the ecosystem.

Of the tree species evaluated in the humid tropics, G. sepium seems to be best suited tree species for use in agroforestry with annual crops. Its principal advantages over the others are its small canopy, its tolerance to frequent pruning, and rapid recovery from shoot pruning. However, it contributes less biomass and nutrients compared to $E$. poeppigiana.

Selection of the appropriate shoot pruning method depends on a number of factors including, purpose of the agroforestry practice, species of woody component, arrangement of the woody component relative to the food crops, and resources available, especially labour. Coppicing is the most severe pruning method and will require a recovering tree to utilise root starch to meet energy needs for regrowth. Some species like G. sepium would be suitable candidates for this method because they have more carbon stored in below ground parts. Pollarding and lopping have a lesser impact on the woody component compared to coppicing and those woody components with small root stores of carbon are better managed using these pruning methods. Coppicing appears more feasible for woodlots where firewood is the main purpose of the agroforestry practice. Lopping appears a more suitable pruning method for shaded cacao (Theobroma cacao L.) and coffee systems, while pollarding appears more suitable for alley cropping systems.

† UNFCCC Special Report, 2000. 
The material cost of pruning is low since only a cutlass (machete) and a sharpening file are all that are needed by one operator to prune trees. Labour costs depend on number of trees to be pruned and method of pruning. Data are not available to allow a comparison of pruning methods in terms of costs.

Modelling presents a unique option to assist in refining the timing of shoot pruning and other operations to assist decision making and resource use. It would appear that available information is adequate to facilitate this, thereby improving the utility of shoot pruning as an important management tool.

Judicious pruning of the shoots of fast growing nitrogen fixing trees is a beneficial way to obtain tree products of use to mankind whilst reducing negative tree-crop interactions and making available to the agroforestry system nutrient rich biomass for soil amelioration and moisture conservation, and plant available nutrients for the associated crops. Adding legume covercrops to such an agro-ecosystem may increase its biological value.

\section{References}

Akinnifesi, F.K., Kang, B.T., Tijani-Eniola, H. (1995). Root size distribution of a Leucaena leucocephala hedgerow as affected by pruning and alley cropping. NFT Research Reports 13:65-69.

Akunda, E. \& Huxley, P.A. (1990). The Application of Phenology to Agroforestry Research. ICRAF Working Paper No. 63. ICRAF, Nairobi. 50pp.

Albrecht, A. \& Kandji, S.T. (2003). Carbon sequestration in tropical agroforestry systems. Agriculture, Ecosystems and Environment 99:15-27.

Anderson, L.S. \& Sinclair, F. (1993). Ecological interactions in agroforestry systems. Agroforestry Abstracts 6:57-91

Bartelink, H.H. (1998), A model of dry matter partitioning in trees. Tree Physiology 18:91-101, ISSN 0829-318X

Bayala, J., Ouedraogo, S.J. \& Teklehaimanot, Z. (2008). Rejuvenating trees in agroforestry systems for better fruit production using crown pruning. Agroforestry Systems 72:187-194, ISSN 0167-4366

Beer, J. (1988). Litter production and nutrient cycling in coffee (Coffea arabica) or cacao (Theobroma cacao) plantations with shade trees. Agroforestry Systems 7:103-114, ISSN 0167-4366

Beer, J., Bonnemann, A., Chavez, W., Fassbender, H.W., Imbach, A.C. \& Martel, I. (1990). Modelling agroforestry systems of cacao (Theobroma cacao) with laurel (Cordia alliodora) or poro (Erythrina poeppigiana) in Costa Rica. Agroforestry Systems 12:229249, ISSN 0167-4366

Beer, J., Muschler, R., Kass, D. \& Somarriba, E. (1998). Shade management in coffee and cacao plantations. Agroforestry Systems 38:139-164, ISSN 0167-4366

Birch, H.F. \& Dougall, H.W. (1967) Effect of a legume on nitrogen mineralisation and percentage N in grass. Plant and Soil 27:292-296, ISSN 0032-079X

Brook, R.M. (1992). Early results from an alley cropping experiment in the humid lowlands of Papua New Guinea. NFTResearch Reports 10:73-76 
Brouwer, R. (1962). Distribution of dry matter in the plant. Netherlands Journal of Agriculture Science 10:361-376, ISSN 0028-2928

Brouwer, R. (1983). Functional equilibrium: sense or nonsense? Netherlands Journal of Agriculture Science 31:335-348, ISSN 0028-2928

Budelman, A. (1990). Woody legumes as live support systems in yam cultivation II. The yam-Gliricidia sepium association. Agroforestry Systems 10:61-69, ISSN 0167-4366

Catchpoole, D.H. \& Blair, G.J. (1990). Forage tree legumes. II Investigation of N transfer to an associated grass using a split root technique. Australian Journal of Agricultural Research 41: 531-537, ISSN 1836-0947

Chadhokar, P.A. (1982). Gliricidia maculata a promising legume fodder plant. World Animal Review 44: 36-43, ISSN 1014-6954

Chandrashekara, U.M. (2007). Effects of pruning on radial growth and biomass increment of trees growing in homegardens of Kerala, India. Agroforestry Systems 69:231-237, ISSN 0167-4366

Chesney, P. \& Nygren, P. (2002). Fine root and nodule dynamics of Erythrina poeppigiana in an alley cropping system in Costa Rica. Agroforestry Systems 56:259-269, ISSN 01674366

Chesney, P. \& Vasquez, N. (2007). Dynamics of non-structural carbohydrate reserves in pruned Erythrina poeppigiana and Gliricidia sepium trees. Agroforestry Systems 69:89105, ISSN 0167-4366

Chesney, P. (2008). Nitrogen and fine root length dynamics in a tropical agroforestry system with periodically pruned Erythrina poeppigiana. Agroforestry Systems 72:149-159, ISSN 0167-4366

Chesney, P.E., Schlönvoigt, A. \& Kass, D. (2000). Producción de tomate con soportes vivos en Turrialba Costa Rica. Agroforesteria en las Américas 7:57-60

Current, D., Lutz, E. \& Scherr, S.J. (1995). Costs, benefits and farmer adoption of agroforestry. In: Costs, Benefits and Farmer Adoption of Agroforestry: Project experience in Central America and the Caribbean, D. Current, E. Lutz, \& S. Scherr, (Eds.), 1-27, The World Bank, Washington, D.C., ISBN 0-8213-3428-X

Davie, S.J. \& Stassen, P.J.C. (1997). The effect of fruit thinning and tree pruning on tree starch reserved and on fruit retention of "sensation" mango trees. Acta Horticulturae 455:160-166, ISSN 0567-7572

Dickman, D. \& Pregitzer, K.S. (1992). The structure and dynamics of woody plant root systems. In: Ecophysiology of Short Rotation Forest Crops, C.P. Mitchell, J.B. FordRobertson, T. Hinckley \& L. Sennerby-Forsse, (Eds), 95-123. Elsevier Applied Science, London, ISBN 978-1-85166-848-9

Dickson, R.E. (1991). Assimilate distribution and storage. In: Physiology of Trees, A.S. Raghavendra, (Ed.), 51-85. John Wiley and Sons, ISBN 10: 0471501107.

Duguma, B., Kang, B.T., \& Okali, D.U.U. (1988). Effect of pruning intensities of three woody leguminous species grown in alley cropping with maize and cowpea on an alfisol. Agroforestry Systems 6:19-35, ISSN 0167-4366

Duhoux, E. \& Dommergues, Y. (1984). The use of nitrogen fixing trees in forestry and soil restoration in the tropics. In: Biological Nitrogen Fixation in Africa, H. Ssali \& S. O. Keya, (Eds.), 384-400. MIRCEN, Nairobi, Kenya 
Erdmann, T.K., Nair, P.K.R. \& Kang, B.T. (1993). Effects of cutting frequency and cutting height on reserve carbohydrates in Gliricidia sepium (jacq.) Walp. Forect Ecology and Management 57:45-60, ISSN 0378-1127

Espeleta, J.F. \& Eissenstat, D.M. (1998). Responses of citrus fine roots to localised soil drying: a comparison of seedlings and adult fruiting trees. Tree Physiology 18:113-119 ISSN 0829-318X

Fownes, J.H. \& Anderson, D.G. (1991). Changes in nodule and root biomass of Sesbania sesban and Leucaena leucocephala following coppicing. Plant and Soil 138:9-16, ISSN 0032-079X

Génard, M., Pages, L. \& Kervella, J. (1998). A carbon balance model of peach tree growth and development for studying the pruning response. Tree Physiology 18:351-362, ISSN 0829-318X

Giller, K.E., Ormesher, J. \& Awah, F.M. (1991). Nitrogen transfer from Phaseolus bean to intercropped maize measured with ${ }^{15} \mathrm{~N}$-enrichment and ${ }^{15} \mathrm{~N}$-isotope dilution methods. Soil Biology and Biochemistry 23:339-346, ISSN 0038-0717

Govindarajan, M., Rao, M.R., Mathuva, M.N. \& Nair, P.K.R. (1996). Soil-water and root dynamics under hedgerow intercropping in semiarid Kenya. Agronomy Journal 88:513-520, ISSN 0002-1962

Grochowska, M.J., Karaszewska, A., Jankowska, B., Maksymiuk, J. \& Williams, M.W. (1984). Dormant pruning influence on auxin, giberellin, and cytokinin levels in apple trees. Journal of American Society for Horticultural Science 109:312-318, ISSN 0003-1062

Haggar, J.P., Tanner, E.V.J., Beer, J.W. \& Kass, D.C.L. (1993). Nitrogen dynamics of tropical agroforestry and annual cropping systems. Soil Biology and Biochemistry 25(10):13631378, ISSN 0038-0717

Hairiah, K. Utomo, W.H. \& van der Heide, J. (1992). Biomass production and performance of leguminous cover crops on an Ultisol in Lampung. Agrivita 15:39-44, ISSN 01260537

Handarayan, E., Giller, K.E. \& Cadisch, G. (1997). Regulating N release from legume tree pruning by mixing residues of different quality. Soil Biology and Biochemistry 29(9/10):1417-1426, ISSN 0038-0717

ICRAF (1996). Annual Report for 1995, ICRAF, Nairobi

Islam, M.S., Hossain, M.A. \& Mondol, M.A. (2008). Effect of pruning and pollarding on shoot development in bakphul (Sesbania grandiflora L.). Journal of Bangladesh Agricultural University 6(2):285-298, ISSN 1810-3030

Jayasundara, H.P.S., Dennet, M.D. \& Sangakkara, U.R. (1997). Biological nitrogen fixation in Gliricidia sepium and Leucaena leucocephala and transfer of fixed nitrogen to an associated grass. Tropical Grasslands 31:529-537, ISSN 0049-4763

Jimenez, J.M., Collinet, J. \& Mazariego, M. (1998). Recuperación de suelos degradados con Gliricidia sepium o gallinaza en la micro cuenca rio Las Cañas, El Salvador. Agroforestería en las Américas 5(20):10-16

Kabeya, D. \& Sakai, S. (2005). The relative importance of carbohydrate and nitrogen for the resprouting ability of Quercus crispula seedlings. Annals of Botany 96(3):479-488, ISSN 0305-7364 
Kandiah, S., Wettasinghe, D.T. \& Wadasinghe, G. (1984). Root influence on shoot development in tea (Camellia sinensis (L.) O. Kuntze) following shoot pruning. Journal of Horticultural Science 59:581-587, ISSN 1462-0316

Kang, B.T. \& Mulongoy, K. (1987). Gliricidia sepium as a source of green manure in an alley cropping system. Proceedings of a Workshop Gliricidia sepium (Jacq.) Walp. Management and Improvement, CATIE, Turrialba, Costa Rica, June 1987. NFTA Special Publication 87-01:44-49

Kang, B.T. (1993). Alley cropping: past achievements and future directions. Agroforestry Systems 23:141-155, ISSN 0167-4366

Kang, H., Shannon, D.A., Prior, S.A. \& Arriaga, F.J. (2008). Hedgerow pruning effects on light interception, water relations and yield in alley-cropped maize. Journal of Sustainable Agriculture 31(4):115-137, ISSN 1044-0046

Karim, A.B. \& Savill, P.S. (1991). Effect of spacing on growth and biomass production of Gliricidia sepium (Jacq.) Walp. in an alley cropping system in Sierra Leone. Agroforestry Systems 16:213-222, ISSN 0167-4366

Kass, D., Jiménez, J. \& Schlönvoigt, A. (1997). Como hacer el cultivo en callejones más productivo, sostenible y aceptable a pequeños productores. Agroforestería en las Américas 4(14):21-23

Kass, DC.L., Jiménez, J., Sánchez, J., Soto, M.L. \& Garzón, H. (1993). Erythrina in alley farming: In Erythrina in the new and old worlds: nitrogen fixing tree res report Special Issue, S.B. Westley \& M.H. Powell (Eds.), 129-137

Keerthisena, R.S.K. (1995). Gliricidia sepium biomass production varies with plant row spacing and cutting height. NFT Research Reports 13:60-63

Kozlowski, T.T. (1992). Carbohydrate sources and sinks in woody plants. Botanical Review. 58(2):107-223, ISSN 0006-8101

Lindarte, E. \& Benítez, C. (1993). Sostenibilidad y agricultura de laderas en América Central, Serie Documentos de Programa 33, IICA, San José, Costa Rica

Loescher, W.H., McCamant, T. \& Keller, J.D. (1990). Carbohydrate reserves, translocation and storage in woody plant roots. HortScience 25:274-281, ISSN 0018-5345

McIntyre, B.D., Riha, S.J. \& Ong, C.K. (1996). Light interception and evapotranspiration in hedgerow agroforestry systems. Agricultural and Forest Meteorology 81:31-40, ISSN 0168-1923

Mulongoy, K. (1983). Field decomposition of leaves of Psophocarpus palustris and Gliricidia sepium on an Alfisol as affected by thidan and benomyl. In: Transactions of Joint Meeting of the British Society of Soil science and Commissions III and IV of the International Society of Soil Science on biological processes and soil fertility, 91. Reading University, England.

Muñoz, F. \& Beer, J. (2001). Fine root dynamics of shaded cocoa plantations in Costa Rica. Agroforestry Systems 51:119-130, ISSN 0167-4366

Muschler, R.G., Nair, P.K.R. \& Melendez, L. (1993). Crown development and biomass production of pollarded Erythrina berteroana, E. fusca and Gliricidia sepium in the humid tropical lowlands of Costa Rica. Agroforestry Systems 24:123-143, ISSN 01674366

Myers, R.J.K., Palm, C.A., Cuevas, E., Gunatilleke, I.U.N. \& Brossard, M. (1994). The synchronization of nutrient mineralization and plant nutrient demand. In: Biological 
Management of Tropical Soil Fertility, P.L. Woomer \& M. J. Swift (Eds.), 81-116. Wiley, United Kingdom, ISSN

Nygren, P. \& Campos, A. (1995). Effect of foliage pruning on fine root biomass of Erythrina poeppigiana (Fabaceae). In: Ecophysiology of Tropical Intercropping, H. Sinoquet \& P. Cruz, (Eds.), 295-302, ISBN 27380006035.

Nygren, P. \& Ramirez, C. (1993). Production and turnover of $\mathrm{N}_{2}$ fixing nodules in relation to foliage development in periodically pruned Erythrina poeppigiana (Leguminosae) trees. Forest Ecology and Management 73:59-73, ISSN 0378-1127

Oelbermann, M. \& Voroney, R.P. (2010). An evaluation of the century model to predict soil organic carbon: examples from Costa Rica and Canada. Agroforestry Systems 82(1):37-50, ISSN 0167-4366

Ong., C.K., Black, C.R., Marshall, F.M. \& Corlett, J.E. (1996). Principles of resource capture and utilization of light and water. In: Tree-Crop Interactions: A physiological approach, C.K. Ong \& P. Huxley (Eds.), 73-158, CAB International, ISBN 085198 $987 \mathrm{X}$

Otu, O.I. \& Agboola, A.A. (1994). The suitability of Gliricidia sepium in in-situ live stake on the yield and performance of white yam (Dioscorea rotundata). Acta Horticulturae 380:360-366, ISSN 0567-7572

Palm, C.A. (1995). Contribution of agroforestry trees to nutrient requirements of intercropped plants. Agroforestry Systems 30:105-124, ISSN 0167-4366

Parrota, J.A. \& Singh, I.P. (1992). Gliricidia sepium root system morphology and biomass allocation. NFT Research Reports 10:169-172

Persson, H. (1979). Fine root production, mortality and decomposition in forest ecosystems. Vegetatio 41:101-109, ISSN 1385-0237

Poudel, D.D., Midmore, D.J. \& Hargrove, W.L. (1998). An analysis of commercial vegetable farms in relation to sustainability to the uplands of Southeast Asia. Agricultural Systems 58(1):107-128, ISSN 0308 521X

Raintree, J.B. (1987). DED User's Manual: An Introduction to Agroforestry Design and Diagnosis. ICRAF, Nairobi, Kenya

Rao, A.V. \& Giller, K.E. (1993). Nitrogen fixation and its transfer from Leucaena to grass using ${ }^{15 N}$. Forest Ecology and Management 61:221-227, ISSN 0378-1127

Ryle, G.J.A., Powell, C.E. \& Gordon, A.J. (1985). Defoliation in white clover: regrowth, photosynthesis and $\mathrm{N}_{2}$ fixation. Annals of Botany 56:9-18, ISSN 0305-7364

Sanchez, P.A. (1995). Science in agroforestry. Agroforestry Systems 30:5-55, ISSN 0167-4366

Sanchez, P.A., Villachica, J.H. \& Brady, D.E. (1983). Soil fertility dynamics after clearing a tropical rainforest in Peru. Soil Science Society of America Journal 47:1171-1178, ISSN 0361-5995

Sanginga, N., Danso, S.K.A., Zapata, F. \& Bowen, G.D. (1994). Influence of pruning management on $\mathrm{P}$ and $\mathrm{N}$ distribution and use efficiency by $\mathrm{N}_{2}$ fixing and non- $\mathrm{N}_{2}$ fixing trees used in alley cropping systems. Plant and Soil 167:219-226, ISSN 0032079X

Shigo, A.L. (1990). Tree branch attachment to trunks and branch pruning. HortScience 25(1):54-59, ISSN 0018-5345

Siddique, A.M. \& Bal, A.K. (1990). Nitrogen fixation in peanut nodules during dark periods and detopped conditions with special reference to lipid bodies. Plant Physiology 95:896-899, ISSN 0032-0889 
Siriri, D., Ong, C.K., Wilson, J., Boffa, J.M. \& Black, C.R. (2010). Tree species and pruning regime affect crop yield on bench terraces in SW Uganda. Agroforestry Systems 78:65-77, ISSN 0167-4366

Somarriba, E., Beer, J. \& Bonnemann, A. (1996). Arboles leguminosas maderables como sombra para cacao. Serie Técnico No. 18, CATIE, Turrialba, Costa Rica

Soule, J. (1985). Glossary for Horticultural Crops. John Wiley \& Sons, ISBN 10: 0471884995

Sprugel, D.G., Hinckley, T.M. \& Schaap, W. (1991). The theory and practice of branch autonomy. Annual Review of Ecology and Systematics 22:309-334

Swift, M.J. (1985). Tropical Soil Biology and Fertility (TSBF): Planning and Research. Biology International Special Issue 9, International Union of Biological Sciences, Paris

Timmer, L.A., Kessler, J.J. \& Slingerland, M. (1996). Pruning of nere trees (Parkia biglobosa (Jacq.) Benth.) on the farmlands of Burkina Faso, West Africa. Agroforestry Systems 33:87-98, ISSN 0167-4366

Tipu, S.U., Hossain, K.L., Islam, M.O. \& Hussain, M.A. (2006). Effect of pruning height on shoot biomass yield of Leucaena leucocephala. Asian Journal of Plant Sciences 5(6):10431046, ISSN 1682-3974

Tschaplinski, T.L. \& Blake, T.J. (1994). Carbohydrate mobilization following shoot defoliation and decapitation in hybrid poplar. Tree Physiology 14:141-151, ISSN 0829-318X

Vaast, P. \& Snoeck, D. (1999). Hacia un manejo sostenible de la material orgánica de la fertilidad biológica de los suelos cafetaleros. In: Desafíos de la Caficultura en Centroamérica. B. Bertrand \& B. Rapidel, (Eds.), 139-169 CIRAD, France.

van Noordwijk, M. \& Purnomosidhi, P. (1995). Root architecture in relation to tree-soil-crop interactions and shoot pruning in agroforestry. Agroforestry Systems 30:161-173, ISSN 0167-4366

van Noordwijk, M., Tomich, T.P., Winahayu, R., Murdiyarso, R., Suyanto, D., Partoharjono, S. \& Fagi, A.M. (Eds.). (1995). Alternatives to Slash and Burn in Indonesia. Summary Report Phase 1. ABS-Indonesia Report No. 4. Bogor, Indonesia. 154p.

Vance, C.P. \&Heichel, G.H. (1991). Carbon in $\mathrm{N}_{2}$ fixation: limitation of exquisite adaptation. Annual Review of Plant Physiology and Plant Molecular Biology 42:373-392

Vanlauwe, B. \& Sanginga, N. (1995). Efficiency of the use of nitrogen from pruning and soil organic matter dynamics in Leucaena leucocephala alley cropping in South-western Nigeria. FAO Fertilizer and Plant Nutrient Bulletin 12:279-292

Vasquez, P.C. \& Quintero, F. (1995). Efecto del diámetro de las estacas de mata ratón (Gliricidia sepium) sobre crecimiento de ramas laterals. Zootecnia Tropical 13(1):113123, ISSN 0798-7269

von Fircks, Y. \& Sennerby-Forsse, L. (1998). Seasonal fluctuations in starch in root and stem tissues of coppiced Salix viminalis plants grown under two nitrogen regimes. Tree Physiology 18:243-249, ISSN 0829-318X

Weeraratna, C.S. (1979). Pattern of nitrogen release during decomposition of some green manures in a tropical alluvial soil. Plant and Soil 53:288-294, ISSN 0032-079X

Wilson, B.F. (1990). The development of tree form. HortScience 25(1):52-54, ISSN 0018-5345 
Wilson, G.F., Kang, B.T. \& Mulongoy, K. (1986). Alley cropping: trees as sources of green manure and mulch in the tropics. Biological Agriculture and Horticulture 3:251-267, ISSN 0144-8765

Young, A. (1981). The potential of agroforestry for soil conservation: Part II Maintenance of soil fertility. Working Paper No. 43. ICRAF, Nairobi 
AGROFORESTRY FOR

BIODIVERSITY AND

ECOSYSTEM SERVICES

SCIENCE ANO PRACTICE

Ededa by Murts Leckion Kionga

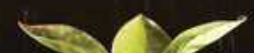

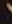

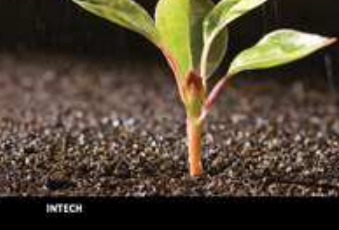

\section{Agroforestry for Biodiversity and Ecosystem Services - Science and Practice}

Edited by Dr. Martin Kaonga

ISBN 978-953-51-0493-3

Hard cover, 164 pages

Publisher InTech

Published online 04, April, 2012

Published in print edition April, 2012

Agroforestry has great potential for reducing deforestation and forest degradation, providing rural livelihoods and habitats for species outside formally protected land, and alleviating resource-use pressure on conservation areas. However, widespread adoption of agroforestry innovations is still constrained by a myriad of factors including design features of candidate agroforestry innovations, perceived needs, policies, availability and distribution of factors of production, and perception of risks. Understanding the science, and factors that regulate the adoption, of agroforestry and how they impact the implementation of agroforestry is vitally important. Agroforestry for Biodiversity and Ecosystem Services: Science and Practice examines design features and management practices of some agroforestry practices and their impact on biodiversity and the ecosystem services it delivers. It also identifies policy issues for facilitating adoption of desirable agroforestry practices and gradual diminution of undesirable policies.

\section{How to reference}

In order to correctly reference this scholarly work, feel free to copy and paste the following:

Patrick E. K. Chesney (2012). Shoot Pruning and Impact on Functional Equilibrium Between Shoots and Roots in Simultaneous Agroforestry Systems, Agroforestry for Biodiversity and Ecosystem Services - Science and Practice, Dr. Martin Kaonga (Ed.), ISBN: 978-953-51-0493-3, InTech, Available from:

http://www.intechopen.com/books/agroforestry-for-biodiversity-and-ecosystem-services-science-andpractice/shoot-pruning-and-impact-on-functional-equilibirum-between-shoots-and-roots-in-simultaneousagrofore

\section{INTECH}

open science | open minds

\section{InTech Europe}

University Campus STeP Ri

Slavka Krautzeka 83/A

51000 Rijeka, Croatia

Phone: +385 (51) 770447

Fax: +385 (51) 686166

www.intechopen.com

\section{InTech China}

Unit 405, Office Block, Hotel Equatorial Shanghai

No.65, Yan An Road (West), Shanghai, 200040, China 中国上海市延安西路65号上海国际贵都大饭店办公楼405单元

Phone: +86-21-62489820

Fax: +86-21-62489821 
(C) 2012 The Author(s). Licensee IntechOpen. This is an open access article distributed under the terms of the Creative Commons Attribution 3.0 License, which permits unrestricted use, distribution, and reproduction in any medium, provided the original work is properly cited. 